\title{
Postural influences on sweating: exploring the effects of gravity and pressure
}

\author{
Norikazu Ohnishi, Sean R Notley, Joonhee Park, Kyoko Tagami, Catriona A Burdon, Elizabeth A Taylor, \\ Nigel AS Taylor \\ From 15th International Conference on Environmental Ergonomics (ICEE XV) \\ Portsmouth, UK. 28 June - 3 July 2015
}

\section{Introduction}

The distribution of thermal sweating is neither uniform nor does it commence simultaneously at all sites. One reason for this variability may be associated with gravitational influences. That is, localised and posturedependent compression of tissues containing pressuresensitive receptors is believed to inhibit sweating from the compressed and ipsilateral sites, whilst enhancing secretion from contralateral surfaces [1]. To evaluate the possibility that local sweat rates might be influenced by gravity, it is necessary to test subjects with and without gravitational loading. This can be achieved by using water immersion to simulate zero gravity, and this experimental model was used for this pilot investigation.

\section{Methods}

Eight males (blindfolded) were first exposed to a supine, resting air exposure (control: $28^{\circ} \mathrm{C}, 60 \%$ relative humidity) wearing a slowly heated, water-perfusion suit $\left(40^{\circ}, 45^{\circ}, 50^{\circ} \mathrm{C}\right)$, and then to a supine water immersion $\left(38^{\circ} \mathrm{C}\right)$. Local sweat rates were measured using ventilated capsules $\left(3.16 \mathrm{~cm}^{2}\right.$; capacitance hygrometry) positioned at two ventral surfaces (forehead, lower chest) and on the dorsal surfaces of the pronated hand and foot. Sweating was tracked until steady states were approximated across all sites.

\section{Results}

Due to the nature of these thermal stimuli, similar, but not identical, auditory canal temperatures were evoked, with immersion producing significantly greater thermal loading: $36.6^{\circ}$ versus $36.9^{\circ} \mathrm{C}$. To adjust for this thermal bias, data were analysed at similar auditory canal temperatures (36.6 ${ }^{\circ}$ [control] and $36.7^{\circ} \mathrm{C}$, respectively), although matching was imperfect, resulting in sweating being evaluated only during transient steady states. When gravitational compression of the dorsal body surfaces was minimised, $72 \%$ of the within-subject and within-site comparisons revealed lower, temperature-dependent sweat rates, even though the matched core temperatures were higher during immersion. This was evident at the forehead, chest and hand in six of eight subjects. Thus, when expressed as sudomotor ratios for each individual (control/immersion) and then averaged across subjects, sweating from the non-compressed surfaces was $>2.5$-fold (forehead), >9.4-fold (chest), $>6.0$-fold (hand) and $>6.4$ fold (foot) higher during the control trial. However, the absolute sweat rate differences were not significant $(P>0.05)$.

\section{Discussion}

Whilst these observations were qualitatively consistent with a neural, hemihidrotic effect [1], it is possible this experiment was under powered, and lacked sufficient control for its more complete expression. Furthermore, since we used partial immersion and not total submersion, then some gravity-induced compression remained. Therefore, whilst it is tempting to speculate that these observations were due to the influence of a buoyancyassociated reduction in skin pressure, which attenuated hemihidrosis, it is probable that multiple mechanisms are involved in the modulation of sweating activity during postural and gravitational variations.

Published: 14 September 2015

* Correspondence: nigel_taylor@uow.edu.au

Centre for Human and Applied Physiology, School of Medicine, University of Wollongong, Wollongong, Australia 


\section{Reference}

1. Takagi K, Sakurai T: A sweat reflex due to pressure on the body surface. Japanese Journal of Physiology 1950, 1:22-28.

doi:10.1186/2046-7648-4-S1-A154

Cite this article as: Ohnishi et al:: Postural influences on sweating: exploring the effects of gravity and pressure. Extreme Physiology \& Medicine 2015 4(Suppl 1):A154.

Submit your next manuscript to BioMed Central and take full advantage of:

- Convenient online submission

- Thorough peer review

- No space constraints or color figure charges

- Immediate publication on acceptance

- Inclusion in PubMed, CAS, Scopus and Google Scholar

- Research which is freely available for redistribution

Submit your manuscript at www.biomedcentral.com/submit
() Biomed Central 